University of Nebraska - Lincoln

DigitalCommons@University of Nebraska - Lincoln

Faculty Publications from the Harold W. Manter Laboratory of Parasitology

August 1997

\title{
Two New Species of Litomosoides (Nemata: Onchocercidae) from Ctenomys opimus (Rodentia: Ctenomyidae) on the Altiplano of Bolivia
}

Sara V. Brant

University of New Mexico, sbrant@unm.edu

Scott Lyell Gardner

University of Nebraska - Lincoln, slg@unl.edu

Follow this and additional works at: https://digitalcommons.unl.edu/parasitologyfacpubs

Part of the Parasitology Commons

Brant, Sara V. and Gardner, Scott Lyell, "Two New Species of Litomosoides (Nemata: Onchocercidae) from Ctenomys opimus (Rodentia: Ctenomyidae) on the Altiplano of Bolivia" (1997). Faculty Publications from the Harold W. Manter Laboratory of Parasitology. 41.

https://digitalcommons.unl.edu/parasitologyfacpubs/41

This Article is brought to you for free and open access by the Parasitology, Harold W. Manter Laboratory of at DigitalCommons@University of Nebraska - Lincoln. It has been accepted for inclusion in Faculty Publications from the Harold W. Manter Laboratory of Parasitology by an authorized administrator of DigitalCommons@University of Nebraska - Lincoln. 


\title{
TWO NEW SPECIES OF LITOMOSOIDES (NEMATA: ONCHOCERCIDAE) FROM CTENOMYS OPIMUS (RODENTIA: CTENOMYIDAE) ON THE ALTIPLANO OF BOLIVIA
}

\author{
Sara V. Brant and Scott Lyell Gardner \\ Division of Parasitology, Harold W. Manter Laboratory, University of Nebraska State Museum, W-529 Nebraska Hall, University of Nebraska- \\ Lincoln, Lincoln, Nebraska 68588-0514
}

\begin{abstract}
Two filarioid nematodes, Litomosoides andersoni $\mathrm{n}$. sp. and Litomosoides ctenomyos $\mathrm{n}$. sp. (Nemata: Onchocercidae), are described from the mesenteries of the subterranean rodent Ctenomys opimus (Rodentia: Hystrichognathi) collected on the altiplano of Bolivia. Specimens collected near Rancho Huancaroma (Oruro Dept.) in 1984 and 1986 can be recognized as undescribed by the structures of the spicules and stoma and the shape of the ovijector. This record represents the first time members of the genus Litomosoides have been recovered from rodents of the family Ctenomyidae; this also represents the first published report of these nematodes from mammals in Bolivia
\end{abstract}

Species of the genus Ctenomys de Blainville occur in all major habitat types in the neotropics south of about latitude $16^{\circ} \mathrm{S}$ in lowland subtropical savanna and about latitude $11^{\circ} \mathrm{S}$ in the high altitude $(>3,500 \mathrm{~m})$ Puna, Altiplano, and Cerrado de Andes (Mares and Ojeda, 1982; Reig, 1986; Contreras et al., 1987). The northern limit of distribution of these subterranean rodents in central lowland Bolivia is about $16^{\circ} 30^{\prime} \mathrm{S}$, defined by the termination of the northernmost extent of the Chaco-dry forest and the beginning of lowland subtropical forest and palmnut savannas (Unzueta, 1975). In lowland Bolivia, ctenomyids occur in friable, well-drained soils (S. L. Gardner, pers. obs.); in the high-altitude region of western Bolivia, these rodents occur in colonies in friable soils throughout their range (S. L. Gardner, pers. obs.). The northern limit of distribution of ctenomyids in high-altitude habitats in the Andes is undefined.

Presently, 39 species of ctenomyids are recognized (Mares and Ojeda, 1982; Wilson and Reeder, 1993); however, in rodents of the genus Ctenomys, levels of variation in diploid and fundamental number of chromosomes are extremely high (Cook and Yates, 1994). Thus, a species of Ctenomys described and defined without data on chromosomes may actually represent a complex of undetected species, and as many as 60 or more cryptic species may exist in southern South America.

Filarioid nematodes of the genus Litomosoides Chandler, 1931 , occur in the abdominal and thoracic cavities of mammals of the orders Didelphimorpha, Chiroptera, and Rodentia in the Neotropical and Nearctic regions (Bain et al., 1989). Filarioid nematodes of the genus Litomosoides have been reported from hosts in the Palearctic region (Gupta and Trivedi, 1989); however, the specimens of Gupta and Trivedi (1989) appear more similar to filarioid nematodes of the genus Litomosa Yorke and Maplestone, 1926.

Scott et al. (1951) detailed the life history of Litomosoides carinii Travassos, 1919, from experimental infections. The cotton rat, Sigmodon hispidus Say and Ord, was used as the definitive host, and the tropical rat mite, Bdellonyssus bacoti (Hirst), was used as the intermediate host. In the arthropod, microfilariae exsheath in the gut, enter the hemocoel, and develop into third-stage juveniles (Anderson, 1992). During the blood meal, the microfilariae are transmitted as infective thirdstage juveniles to the definitive host (mammal). Within the circulatory system of the definitive host, third-stage microfilariae

Received 2 October 1995; revised 3 February 1997; accepted 3 February 1997. undergo an additional molt to fourth-stage juveniles that later molt into adults in the mesenteries.

Subsequent to the work by Scott et al. (1951), additional life cycle experiments were conducted with Litomosoides galizae Bain, Petit, and Diagne, 1989, Litomosoides petteri Bain, Petit, and Berteaux, 1980, and Litomosoides legerae Bain, Petit, and Berteaux, 1980 , using $B$. bacoti as the intermediate host. These experimental infections were used to characterize more completely the details of microfilariae at each stage in the life cycle (Bain et al., 1980, 1989). However, except for the work by Forrester and Kinsella (1973), there have been no experiments on host specificity and identity of the intermediate hosts for those species of Litomosoides.

The present paper includes the descriptions of 2 new species of filarioid nematodes of the genus Litomosoides sensu Gardner and Schmidt, 1986, found in the mesenteries of rodents of the genus Ctenomys (Rodentia: Ctenomyidae) collected in 1984 and 1986 from a single locality on the altiplano of Bolivia.

\section{MATERIALS AND METHODS}

Individual nematodes that we determined represent 2 new species of the genus Litomosoides were recovered from Ctenomys opimus Wagner collected in Bolivia during May through August in the years 1984 and 1986. These collections were part of a larger study to survey the biodiversity of the parasites of mammals of Bolivia. Blood smears were prepared, fixed in $100 \%$ methanol, stained with Wright's stain, and examined for the presence of microfilariae. Adult filarioid nematodes were isolated from the abdominal and thoracic regions of freshly killed hosts and were killed in glacial acetic acid. The adult filarioid nematodes were then fixed in $10 \%$ formalin or stored in $70 \%$ ethanol.

In the laboratory, specimens were cleared over a period of 5-7 days by evaporation of a solution of $70 \%$ ethanol, $2 \%$ glycerol, and $2 \%$ lactic acid. Quantitative measurements were taken using both a calibrated ocular micrometer and a computer-aided image measurement system. Drawings were made with the aid of a drawing tube. Microfilariae were dissected from broken females for detailed drawing and measurement. In the description, $\mathrm{n}=$ number of individuals, $\mathrm{SD}=$ standard deviation, $\mathrm{CV}=$ coefficient of variation, and means are in parentheses.

\section{DESCRIPTION}

Litomosoides andersoni $\mathrm{n}$. sp.

(Figs. 1-14)

General: With characters of the genus (sensu Gardner and Schmidt, 1986). Males about $1 / 2$ length of females. Lateral amphids visible with slightly narrowing cephalic extremity. Reduced lateral alae (Fig. 14). Well-cuticularized stoma wider than long, expanding posteriad to a width greater than the anterior part; posterior $1 / 2$ of the stoma embedded in the muscular part of esophagus. Nerve ring about $1 / 3$ distance from anterior extremity (Fig. 1); excretory pore at level of nerve ring. Long 


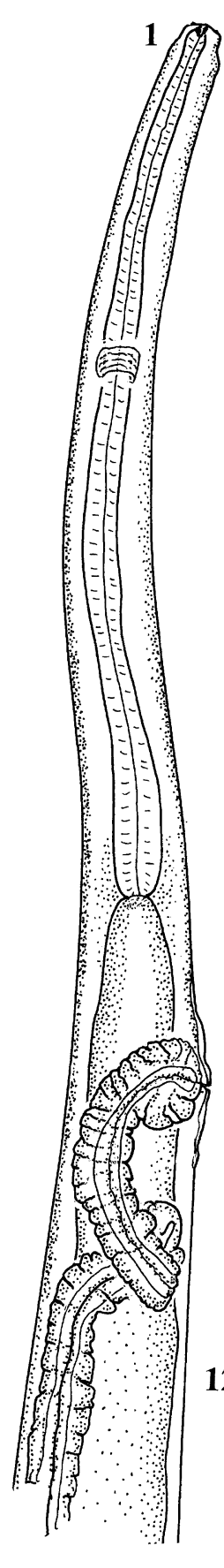

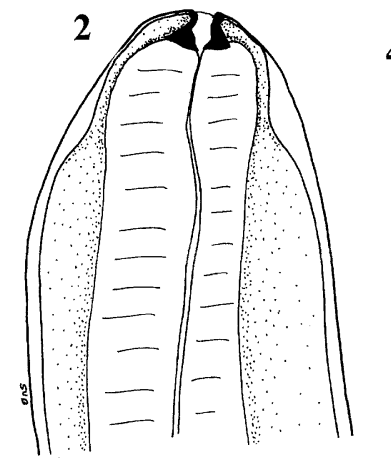

4

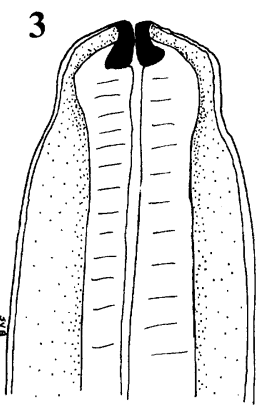

6
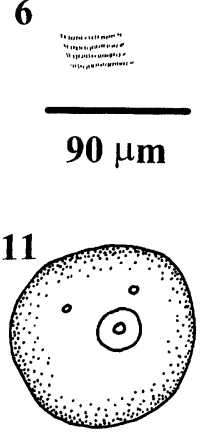

$27 \mu \mathbf{m}$

10

$150 \mu \mathbf{m}$

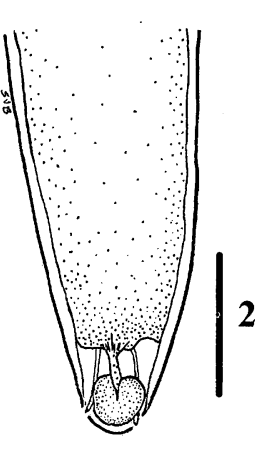

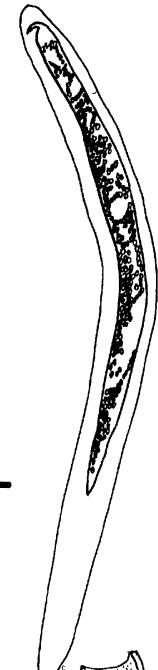
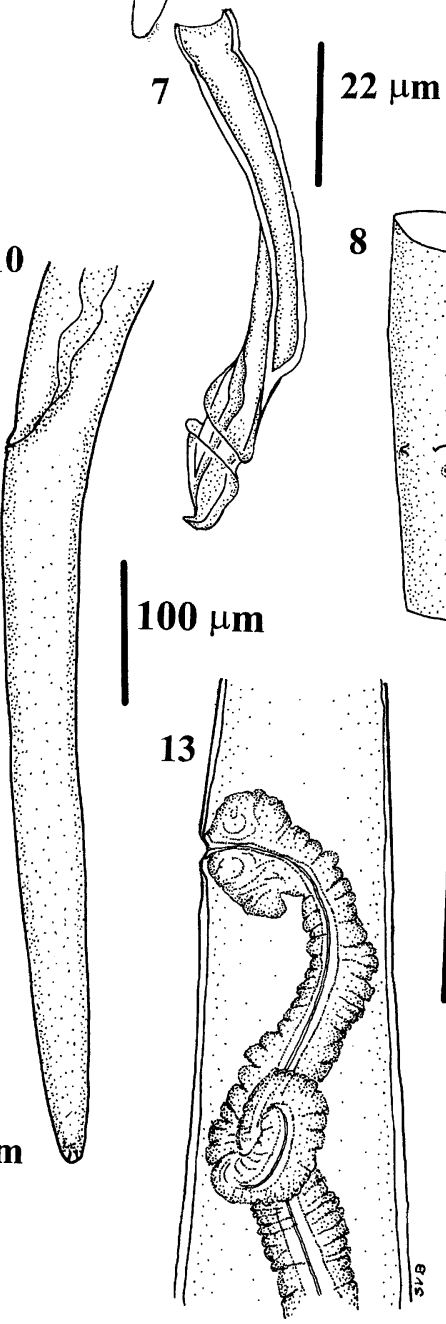

$22 \mu \mathbf{m}$
5
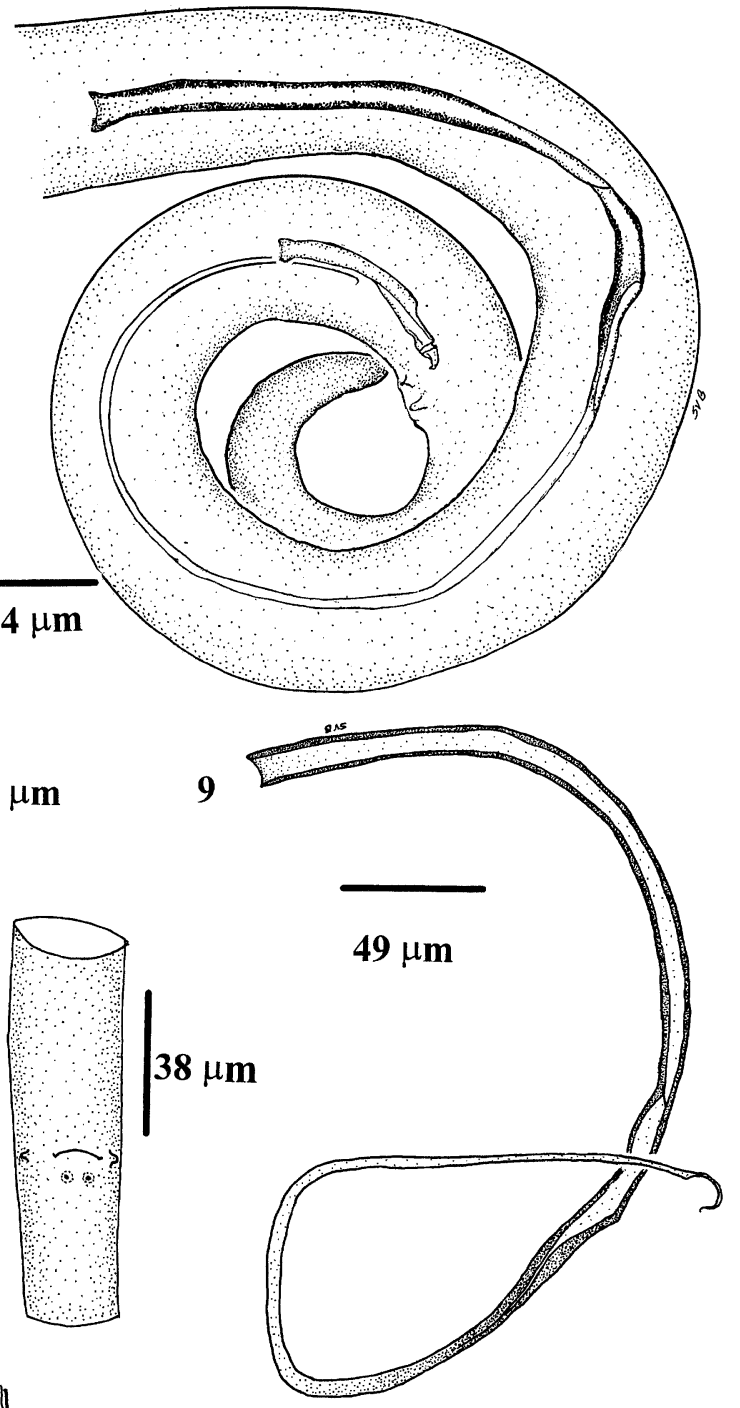

$20 \mu \mathbf{m}$
8

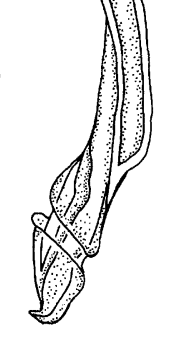

13

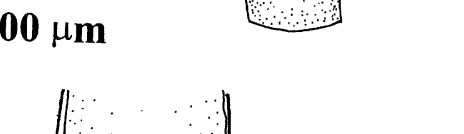

FigurEs 1-14. Drawings of Litomosoides andersoni n. sp. (scale bar same for Figs. 2-4). 1. Anterior end of female showing positions of the nerve ring and ovijector. 2. Anterior end of female showing detail of the stoma. 3. Anterior end of male showing detail of the stoma. 4. Microfilaria extracted from the uterus. 5. Posterior end of male showing the position of the spicules and papillae. 6. Area rugosa. 7. Right spicule. 8. Cloacal papillae. 9. Left spicule. 10. Tail of female showing phasmid ducts. 11. En face, note lack of any visible structures. 12. Tail of female. 13. Ovijector. 14. Cross section of male at mid-body. 
and tapering tail (Fig. 10). Sheath of microfilaria longer than body, with longest part at tail (Fig. 4).

Male: $\mathrm{n}=16$, total length $21-31(27) \mathrm{mm}, \mathrm{SD}=2 \mathrm{~mm}, \mathrm{CV}=0.09$ Maximum body width 119-172 (147), SD $=15, \mathrm{CV}=0.11$. Anterior body width $25-43(37), \mathrm{SD}=4, \mathrm{CV}=0.12$. Width of stoma $4-10(8)$ $\mathrm{SD}=2, \mathrm{CV}=0.24$. Length of stoma $3-8(5), \mathrm{SD}=1, \mathrm{CV}=0.24$ Body width at base of esophagus 56-74 (64), $\mathrm{SD}=5, \mathrm{CV}=0.07$ Length of esophagus 501-764 (661), $\mathrm{SD}=77, \mathrm{CV}=0.12$. Esophagus width at midpoint $15-37(23), \mathrm{SD}=5, \mathrm{CV}=0.24$. Distance from nerve ring to anterior end 220-531 (362), $\mathrm{SD}=71, \mathrm{CV}=0.20$. Body width at nerve ring 31-65 (49), $\mathrm{SD}=7, \mathrm{CV}=0.14$. Length of left spicule 286-654 (556), SD $=125, \mathrm{CV}=0.23$

Description of spicules: Left spicule. Length of calomus 127-316 (211), $\mathrm{SD}=45, \mathrm{CV}=0.21$; width of manubrium 7-17 (13), $\mathrm{SD}=2$ $\mathrm{CV}=0.18$; length of vellum 53-160 (90), $\mathrm{SD}=32, \mathrm{CV}=0.36$; length of lamina 79-459 (326), SD $=113, \mathrm{CV}=0.35$. Lamina and calomus relatively well cuticularized; calomus slightly longer than membranous lamina. Lamina narrows to a thin flagellum, terminating in a very thin small hook (Fig . 9). Right spicule. Length 65-101 (77), SD = 8, CV $=0.10$, much shorter than left spicule. From manubrium, calomus relatively long, tapering posteriad with a complex lamina and vellum terminating in a sharp hook (Fig. 7). Spicules similar to those described for the "carinii" group defined by Bain et al. (1989) (see Diagnosis). Length of tail $140-272(216), \mathrm{SD}=30, \mathrm{CV}=0.14$. Body width at cloaca $38-57(46), \mathrm{SD}=5, \mathrm{CV}=0.10$. No post-cloacal papillae; 2 pairs of cloacal papillae (Fig. 8); tail with 4 or 5 coils.

Female: $\mathrm{n}=14$, length $61-81 \mathrm{~mm}(69), \mathrm{SD}=7 \mathrm{~mm}, \mathrm{CV}=0.10$. Maximum body width 244-367 (296), $\mathrm{SD}=32, \mathrm{CV}=0.11$. Anterior width of body 30-74 (42), SD $=13, \mathrm{CV}=0.30$. Width of body at base of esophagus 71-116 (98), $\mathrm{SD}=14, \mathrm{CV}=0.14$. Length of stoma 4-7 (5), SD $=1, \mathrm{CV}=0.19$. Width of stoma 5-13 (10), SD $=2$, CV $=0.23$. Esophagus length 632-924 (788), $\mathrm{SD}=75, \mathrm{CV}=0.10 . \mathrm{Esoph}$ agus width $23-35$ (29), $\mathrm{SD}=3, \mathrm{CV}=0.12$. Distance from nerve ring to anterior end 322-693 (450), SD $=135, \mathrm{CV}=0.30$. Body width at nerve ring $51-100(66), \mathrm{SD}=12, \mathrm{CV}=0.18$. Distance from vulva to anterior end 863-1,198 (972), SD $=89, \mathrm{CV}=0.09$. Body width at vulva 97-157 (125), $\mathrm{SD}=16, \mathrm{CV}=0.13$. Vulva immediately posterior to esophageal-intestinal junction, ovijector muscular, forming a loop just posterior to vagina (Figs. 1, 13). Body width at anus 58-94 (73), $\mathrm{SD}=10, \mathrm{CV}=0.13$. Length of tail 201-675 (539), $\mathrm{SD}=139, \mathrm{CV}=$ 0.26 . Tail with phasmids clearly visible (Fig. 10).

Microfilaria: From specimens dissected from uterus of female nematode, mean measurement lengths including sheath $(n=10)$ : length 65 , width 5. Sheath of microfilaria longer than body, with longest part of sheath at posterior end (Fig. 4). From specimens measured without sheath in blood smear, mean measurements $(n=100)$ : length 37 , width 6 .

\section{Taxonomic summary}

Symbiotype: Holosymbiotype: Ctenomys opimus, American Museum of Natural History (AMNH) catalog no. 260839; field collection no. SG\#61-84; Museum of Southwestern Biology (MSB), Division of Biological Materials, New Mexico, kryovoucher no. NK11511. Allosymbiotype: Ctenomys opimus, AMNH catalog no. 260843; field collection no. SG133-84; MSB Division of Biological Materials, New Mexico, kryovoucher no. NK11583. Collected August 1984.

Type locality: $3.5 \mathrm{~km}$ northeast of Rancho Huancaroma, Departamento de Oruro, Bolivia, South America $\left(17^{\circ} 40^{\prime} \mathrm{S}, 67^{\circ} 27^{\prime} \mathrm{W}\right.$, elev. 4,000 $\mathrm{m})$.

Specimens deposited: Holotype male (NK11511G): H. W. Manter Laboratory (HWML) 39122. Allotype female (NK11583AA): HWML 39123.

Etymology: Named in honor of Dr. Sydney Anderson, leader of our field expeditions and a pioneering mammologist in Bolivia.

Prevalence: In 1984, 9/22 (40\%) of individuals of C. opimus examined from the type locality were infected with $L$. andersoni.

\section{Diagnosis}

Litomosoides andersoni n. sp. can be distinguished from all other species of Litomosoides except L. thomomydis Gardner and Schmidt, 1986, and L. westi Gardner and Schmidt, 1986, by the structure of the stoma. These 3 species possess a stoma that is broader than long with most of the posterior part being embedded in the esophagus. However, the stoma of $L$. andersoni is shorter and thicker and possesses a different shape than those of $L$. thomomydis and $L$ westi.

Litomosoides andersoni $\mathrm{n}$. sp. can also be distinguished from L. thomomydis by the shape of the spicules; in $L$. andersoni, the right spicule terminates distally in a sharp hook, whereas the lamina of the right spicule of $L$. thomomydis is more rounded and lacks a hook. The spicules resemble those of the "carinii" group as defined by Bain et al. (1989; p. 285) in the following: "Dans le deuxiéme type, représenté par $L$ carinii et $L$. scotti, le spicule droit est sclérifié jusqu'à son extrémité distale, avec un bourrelet subterminal, bien marqué sur la face dorsale, qui peut délimiter un capuchon terminal ( $L$. carinii); le talon est fort. Le spicule gauche a une lame composée d'une partie simple et bien sclérifée, plus courte que la manche; la partie postérieure entiérement membraneuse n'est bien visible que chez $L$. scotti."

Litomosoides andersoni can be differentiated from $L$. westi on the shape of the tail; $L$. andersoni lacks any caudal projections, whereas $L$. westi has a tail ending in 3 well-developed points (see Gardner and Schmidt, 1986)

\section{Litomosoides ctenomyos n. sp.}

$$
\text { (Figs. 15-28) }
$$

General: With characters of the genus (sensu Gardner and Schmidt, 1986). Viewed en face, cephalic extremity lacking visible structures. Cylindrical stoma longer than wide with irregularly thickened walls, about $1 / 4$ of stoma embedded in esophagus (Figs. 16, 17). Nerve ring located about $1 / 4$ of length of esophagus from anterior end (Fig. 15), excretory pore at level of nerve ring. Reduced lateral alae (Fig. 27). Sheath of microfilariae about the length of the body (Fig. 19).

Male: $\mathrm{n}=6$. Total length 27-31 (28) $\mathrm{mm}, \mathrm{SD}=1 \mathrm{~mm}, \mathrm{CV}=0.05$. Maximum body width 92-170 (140), $\mathrm{SD}=27, \mathrm{CV}=0.19$. Body width at anterior end 39-43 (41), $\mathrm{SD}=1, \mathrm{CV}=0.03$. Stoma width 7-9 (8), $\mathrm{SD}=1, \mathrm{CV}=0.11$; stoma length $13-18(15), \mathrm{SD}=2, \mathrm{CV}=0.10$. Body width at esophagus base 60-77 (67), $\mathrm{SD}=6, \mathrm{CV}=0.09$. Esophagus length $511-730(640), \mathrm{SD}=75, \mathrm{CV}=0.11$; esophagus width 24-28 (25), $\mathrm{SD}=2, \mathrm{CV}=0.06$. Distance of nerve ring to anterior end $205-425(317), \mathrm{SD}=90, \mathrm{CV}=0.28$. Width of body at nerve ring $56-$ $61(58), \mathrm{SD}=2, \mathrm{CV}=0.04$

Description of spicules: Spicules similar to those described for the "sigmodontis" group by Bain et al. (1989). Right spicule much shorter than left. Manubrium and calomus well cuticularized, much longer than the lamina portion of the spicule. Lamina without vellum, strongly cuticularized. Spicule tapers posteriorly ending in a slender tip (Fig. 28). Right spicule less cuticularized than those usual for the carinii group, blade is lacking a phalange and it tapers with 2 cuticular borders. Length of right spicule 73-91 (81), $\mathrm{SD}=7, \mathrm{CV}=0.08$. Left spicule long and slender; calomus and lamina portions of almost equal proportions. Vellum relatively well developed, extending from the junction of the calomus and the lamina, disappearing in about the distal $1 / 8$ of the length of the spicule. Distal portion becoming narrow and ending in a rodlike structure with a slightly hooked terminus (Fig. 20). Blade simple and longer than handle, vellum not as well developed as those of the carinii group. Length of left spicule 189-385 (296), $\mathrm{SD}=66, \mathrm{CV}=0.22$; calomus length 119-131 (125), $\mathrm{SD}=5, \mathrm{CV}=0.03$; manubrium width $7-14$ (12), $\mathrm{SD}=3, \mathrm{CV}=0.21$; lamina length 143-192 (160), $\mathrm{SD}=$ $19, \mathrm{CV}=0.11$; vellum length $32-71(52), \mathrm{SD}=14, \mathrm{CV}=0.26$; tail length $151-194$ (171), $\mathrm{SD}=16, \mathrm{CV}=0.09$

Body width at cloaca 45-51 (48), $\mathrm{SD}=2, \mathrm{CV}=0.04$. Number of cloacal papillae $6-12(10), \mathrm{SD}=2, \mathrm{CV}=0.20$. Tail rounded with $4-$ 5 coils, 8-9 post-cloacal papillae and 1 pair of cloacal papillae (Figs. $18,21)$

Female: $\mathrm{n}=5$. Maximum body width $264-333(300), \mathrm{SD}=25, \mathrm{CV}$ $=0.08$. Width at anterior end 44-62 (569), $\mathrm{SD}=7, \mathrm{CV}=0.13$. Body width at esophagus base 98-144 (116), $\mathrm{SD}=17, \mathrm{CV}=0.15$. Stoma length 17-20 (18), $\mathrm{SD}=2, \mathrm{CV}=0.06$; stoma width 6-11 (9), $\mathrm{SD}=$ $2, \mathrm{CV}=0.22$. Length of esophagus 833-872 (853), $\mathrm{SD}=17, \mathrm{CV}=$ 0.02 . Width of esophagus 27-39 (31), $\mathrm{SD}=5, \mathrm{CV}=0.15$. Length of nerve ring to anterior $110-598(416), \mathrm{SD}=186, \mathrm{CV}=0.45$. Body width at nerve ring 70-118 (91), $\mathrm{SD}=20, \mathrm{CV}=0.22$. Vulva posterior to esophagus with a bulbous muscular ovijector (Figs. 15, 23). Distance from vulva to anterior end $1,125-2,170(1,474), \mathrm{SD}=415, \mathrm{CV}=0.28$. Body width at vulva $124-181(158), S D=21, C V=0.14$. Tail tapers with visible phasmids (Figs. 24, 26).

Microfilaria: From specimens dissected from uterus of female nem- 


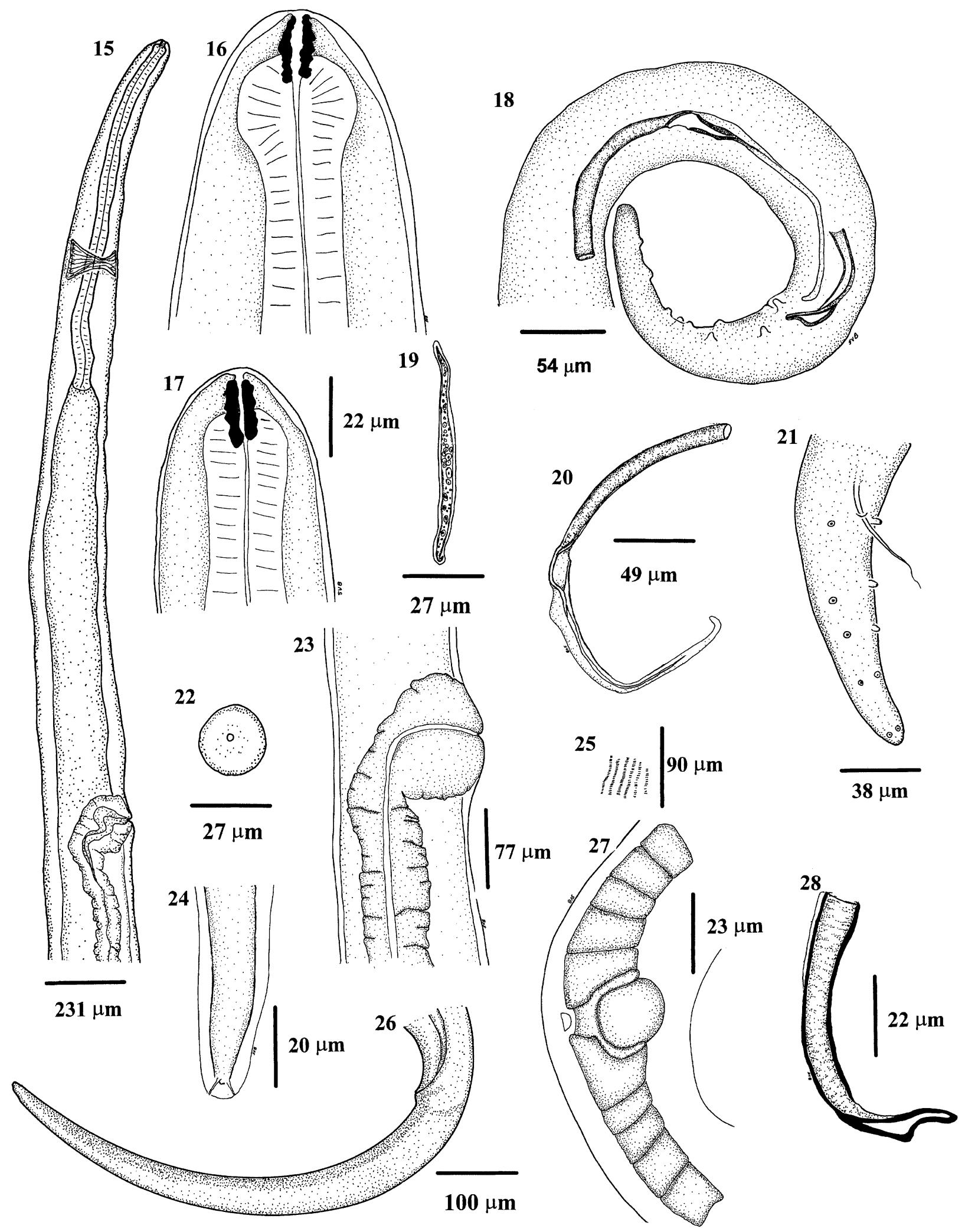

FiguRES 15-28. Drawings of Litomosoides ctenomyos $\mathrm{n}$. sp. (scale bar same for Figs. 16, 17). 15. Anterior end of female showing positions of the nerve ring and the ovijector. 16. Anterior end of the female showing detail of the stoma. 17. Anterior end of the male showing detail of the stoma. 18. Posterior end of the male showing positions of the spicules and the cloacal and post-cloacal papillae. 19. Microfilaria extracted from uterus. 20. Left spicule. 21. Cloacal and post-cloacal papillae. 22. En face. 23. Ovijector. 24. Tail of female. 25. Area rugosa. 26. Tail of female showing phasmid ducts. 27. Cross section of male at mid-body. 28. Right spicule. 
atode, mean measurements $(n=10)$ : length 72 , width 5 . Sheath of microfilaria about length of body (Fig. 19). No microfilaria were found in blood smears.

\section{Taxonomic summary}

Symbiotype: Holosymbiotype: Ctenomys opimus, MSB Division of Mammals catalog no. 57198; Division of Biological Materials, New Mexico, kryovoucher no. NK14766. Field collection number SG32886. Collected October 1986.

Type locality: $3.5 \mathrm{~km}$ northeast of Rancho Huancaroma, Departamento de Oruro, Bolivia, South America $\left(17^{\circ} 40^{\prime} \mathrm{S}, 67^{\circ} 27^{\prime} \mathrm{W}\right.$, elev. 4,000 $\mathrm{m})$.

Specimens deposited: Holotype male (NK14766B): HWML 39124 Allotype female (NK14766A): HWML 39125.

Etymology: Named after the genus of host, meaning "of Ctenomys."

Prevalence: In 1986, 2/8 (25\%) of individuals of C. opimus examined from the type locality were infected with $L$. ctenomyos.

\section{Diagnosis}

Litomosoides ctenomyos n. sp. can be distinguished from L. carinii L. scotti Forrester and Kinsella, 1973, L. silvae Padilha and de Faria 1977, L. guiterasi (Vigueras, 1934) Sandground, 1934, L. brasiliensi Almeida, 1936, L. molossi Esslinger, 1973, L. chandleri Esslinger, 1973, and $L$. petteri based on the shape of the right spicule as described by Bain et al. (1989) for the "carinii" group. The lamina of the right spicule of L. ctenomyos is smooth and tapering, lacking the hooked phalange at the terminus. Litomosoides ctenomyos most closely resembles L. barretti Muller, 1980, L. teshi Esslinger, 1973, L. esslingeri Bain, Petit, and Diagne, 1989, L. sigmodontis Chandler, 1931, and L. leonilavazquezae Caballero and Caballero, 1931, based on stoma and spicule structure. The spicules resemble those of the "sigmodontis" group as defined by Bain et al. (1989; p. 285) in the following: "Dans l'un, représenté par $L$. sigmodontis, L. galizai n. sp. et $L$. kohnae n. sp., le spicule droit est peu sclérifié; sa région distale est effilée, soutenue par deux fines baguettes cuticulaires, et se termine par une coute languette membraneuse, en général repliée dorsalement sous le spicule; la talon est souvent peu saillant. Le spicule gauche a une lame constituée d'un axe sclérifié plus long que le manche; la moitié antérieure est bordée par de larges ailes membraneuses, plissées longitudinalement et donc bien visibles même sans dissection.

Litomosoides ctenomyos can be distinguished from $L$. barretti by the shape of the right spicule and the lack of papillae near the tip of the tail; from L. teshi in the shape of the stoma and the shape of the tail in the female, and from $L$. sigmodontis in lacking anteriorly directed cephalic structures (papillae) and in the shape of the spicules. Litomosoides ctenomyos can be differentiated from $L$. leonilavazquezae by the size of the body of both males and females and the greater number of unpaired post-cloacal papillae.

\section{DISCUSSION}

The finding of filarioid nematodes of the genus Litomosoides in rodents of the family Ctenomyidae from Bolivia greatly increases the known host range and known geographic distribution of these filarioid nematodes. Rodents of the genus Ctenomys exhibit a strongly subterranean lifestyle (Nevo, 1979). Our observations of individuals of $C$. opimus in colonies in at least 3 different geographic localities in Bolivia indicate that these rodents rarely emerge completely from their burrow systems during daylight hours. On several occasions at 1 locality (Bolivia: Cruce Ventilla, $19^{\circ} 08^{\prime} \mathrm{S}, 66^{\circ} 07^{\prime} \mathrm{W}$, elev. 3,950), individuals of $C$. opimus were collected from the same burrow systems from which were collected rodents of the genera Galea Meyen (Hystricognathi: Caviidae) and Phyllotis Waterhouse (Sciurognathi: Muridae). At this locality, no adult helminths were found that were shared by other rodents living syntopically with C. opimus. The rodents of the genera Galea, Ctenomys, and Phyllotis represent 2 major phylogenetic lineages: 1 lineage in the Hystricognathi Tulberg and 1 lineage in the Sigmodontinae Wagner. Only 1 species of helminth (represented by metacestodes of Taenia talicei Dollfus, 1960) was found to be shared among species of Galea, Ctenomys, and Phyllotis sharing burrow systems.

It is interesting to note the morphological similarities in the stoma of L. andersoni, L. thomomydis, and L. westi. The latter 2 species occur only in rodents of the family Geomyidae in the central Nearctic region. Geomyoid rodents are a relatively old group, having originated in North America with no evidence of a fossil history outside the Nearctic region (Russell, 1968). Members of the family Geomyidae occur from southern Canada south through suitable habitat across the isthmus of Panama into northern Colombia in South America, whereas ctenomyid rodents have a strictly southern neotropical distribution, having originated from hystricognath ancestors, perhaps as late as the Pliocene (Gardner, 1991). There is no evidence of any possible contact between geomyids and ctenomyids; therefore, the similarity of morphological characters between at least 2 species of their nematodes appears to be a result of morphological convergence. It is also possible that there may have been a host switch from an ancestor derived from the Nearctic region. The questions presented above can probably be answered most readily by performing an historical-phylogenetic analysis including species of both Litomosoides and Litomosa using data derived from studies of both morphological and molecular characters. This analysis would provide some spatial/temporal frame that would allow an understanding of the diversification of members of these genera of nematodes.

\section{ACKNOWLEDGMENTS}

The work was supported in large part by the National Science Foundation (BSR-8612329 to S. L. Gardner, D. W. Duszynski, and T. L. Yates; BSR-9024816 and DEB-9496263 to S. L. Gardner; BSR-8408923 to T. L. Yates; BSR-8316740 to S. A. Anderson). Additional support was provided directly by the American Museum of Natural History, The Museum of Southwestern Biology, and the Tinker Foundation. The following organizations provided either specimens or logistic support in the field: El Museo National de Historia Natural, La Paz; The Museum of Southwestern Biology, The University of New Mexico; and El Instituto Boliviano de Biologia de la Altura, La Paz, Bolivia. We thank the following people for help in various stages of the work: S. Anderson, S. Bandoni, J. Cook, M. Campbell, A. Chabaud, F. Davis, P. Desjeux, A. Dickerman, D. Duszynski, P. Ford, W. Gannon, J. P. Hugot, O. Jordan, C. Lambert, J. Machula, J. Miralles, D. Moore, N. Olds, J. Salazar, G. Schmidt, C. Schuster, and C. Vaucher. For specimens, we also thank O. Bain, A. Chabaud, J.-P. Hugot, and A. Petter from the National Museum of Natural History, Paris, France.

\section{LITERATURE CITED}

Anderson, R. C. 1992. Nematode parasites of vertebrates: Their development and transmission. CAB International, Wallingford, Oxon, U.K., $578 \mathrm{p}$

Bain, O., G. Petit, and S. Berteaux. 1980. Description de deux nouvelles filaires du genre Litomosoides et de leurs stades infestants. Annales de Parasitologie Humaine et Comparee 55: 225-237.

- , AND M. DiAgne. 1989. Etude de quelques Litomosoides parasites de rongeurs; consequences taxonomiques. Annales de Parasitologie Humaine et Comparee 64: 268-289. 
Contreras, L. C., J. C. Torres-Mura, and J. L. Yanez. 1987. Biogeography of octodontid rodents: An eco-evolutionary hypothesis. In Studies in neotropical mammalogy, essays in honor of Philip Herschkovitz, B. D. Patterson and R. M. Timm (eds.). Fieldiana Zoology 39: 401-411.

CoOK, J. A., AND T. L. YATES. 1994. Systematic relationships of the Bolivian tuco-tucos, genus Ctenomys (Rodentia, Ctenomyidae). Journal of Mammalogy 75: 583-599.

Forrester, D. J., AND J. M. Kinsella. 1973. Comparative morphology and ecology of two species of Litomosoides (Nematoda: Filarioidea) of rodents in Florida, with a key to the species of Litomosoides Chandler, 1931. International Journal for Parasitology 3: 255-263.

GardNer, S. L. 1991. Phyletic coevolution between subterranean rodents of the genus Ctenomys (Rodentia: Hystricognathi) and nematodes of the genus Paraspidodera (Heterakoidea: Aspidoderidae) in the Neotropics: Temporal and evolutionary implications. Zoological Journal of the Linnean Society 102: 169-201.

, AND G. D. SCHMIDT. 1986. Two new species of Litomosoides (Nematoda: Onchocercidae) from pocket gophers (Rodentia: Geomyidae) in Colorado. Systematic Parasitology 8: 235-242.

Gupta, S. P., AND K. K. Trivedi. 1989. Two new species of Litomosoides. Indian Journal of Helminthology 41: 153-161.

Mares, M. A., AND R. A. OJedA. 1982. Patterns of diversity and ad- aptation in South American hystricognath rodents In Mammalian biology in South America, M. A. Mares and H. H. Genoways (eds.). Pymatuning Laboratory of Ecology (special publication) 6: 393-432.

Nevo, E. 1979. Adaptive convergence and divergence in subterranean mammals. Annual Review of Ecology and Systematics 10: 269308.

REIG, O. A. 1986. Diversity patterns and differentiation of high Andean rodents. In High altitude tropical biogeography, F. M. Vuilleunier and M. Monasterio (eds.). Oxford University Press, Oxford, U.K., p. 404-439.

RuSSELl, R. J. 1968. Evolution and classification of the pocket gophers of the subfamily Geomyinae. University of Kansas Publications, Museum of Natural History 16: 473-579.

Scott, J. A., E. E. Macdonald, AND B. Terman. 1951. A description of the stages in the life cycle of the filarial worm Litomosoides carinii. Journal of Parasitology 37: 425-432.

Uzueta, O. Q. 1975. Mapa ecologico de Bolivia. Minesterio de Asuntos Campesinos y Agropecuarios, La Paz, Bolivia.

Wilson, D. E., AND D. M. ReEdER. 1993. Mammal species of the world: A taxonomic and geographic reference. Smithsonian Institution Press, Washington, D.C. and London in association with the American Society of Mammalogists, 1,206 p. 